\title{
KECEMASAN DAN LAMANYA WAKTU MENJALANI HEMODIALISIS BERHUBUNGAN DENGAN KEJADIAN INSOMNIA PADA PASIEN GAGAL GINJAL KRONIK
}

\author{
Ida Rosdiana ${ }^{1 *}$, Krisna Yetty ${ }^{2}$, Luknis Sabri ${ }^{3}$ \\ 1. Jurusan Keperawatan, Poltekkes Kemenkes Tasikmalaya, Tasikmalaya 46115, Indonesia \\ 2. Fakultas Ilmu Keperawatan, Universitas Indonesia, Depok 16424, Indonesia \\ 3. Fakultas Kesehatan Masyarakat, Universitas Indonesia, Depok 16424, Indonesia \\ *E-mail: idarosdiana_27@yahoo.co.id
}

\begin{abstract}
Abstrak
Insomnia merupakan gangguan tidur yang paling sering terjadi pada pasien hemodialisis, prevalensinya lebih tinggi dibanding pada populasi umum. Berbagai faktor yang diduga berhubungan dengan terjadinya insomnia pada pasien hemodialisis adalah demografi, gaya hidup, psikologis, biologis, dan faktor dialisis. Tujuan penelitian potong lintang ini untuk mengidentifikasi faktor yang berhubungan dengan kejadian insomnia pada pasien yang menjalani hemodialisis. Sebanyak 106 responden yang berasal dari RSUD Kota Tasikmalaya dan Garut dilibatkan. Hasil penelitian menunjukkan bahwa insomnia dialami oleh $58(54,7 \%)$ responden, dengan rerata usia 47,66 $\pm 13,36$ tahun. Tidak ditemukan hubungan antara insomnia dengan faktor demografi, gaya hidup, faktor biologis, shift HD dan $\mathrm{Kt} / \mathrm{V}$ hemodialisis. Insomnia berhubungan dengan kecemasan $(\mathrm{p}=0,007 ; \mathrm{OR}=3,3)$, dan lama waktu menjalani hemodialisis $(\mathrm{p}=0,040 ; \mathrm{OR}=2,48)$. Kecemasan dan lama waktu menjalani hemodialisis merupakan faktor independen yang berhubungan dengan kejadian insomnia. Perlu dilakukan penelitian lanjutan, yaitu menguji variabel lain seperti keluhan fisik akibat kondisi uremia yang sering dialami pasien hemodialisis.
\end{abstract}

Kata kunci: gagal ginjal kronik, hemodialisis, insomnia, kecemasan

\begin{abstract}
Anxiety and the Length of Time Undergoing Hemodialysis Related to Insomnia in Chronic Kidney Diseases Patients. Insomnia is a sleep disorder that frequently occurs in hemodialysis patients. The prevalence was higher than in the general population. Several factors were thought having significant relationship with the occurrence of insomnia in hemodialysis patients, namely demographic, lifestyle, psychological, biological and dialysis factors. The purpose of this study was to identify factors associated with insomnia in Chronic Kidney Diseases patients undergoing hemodialysis. This study used cross-sectional study design, with a total sample of 106 respondents who visited hemodialysis unit at Tasikmalaya and Garut City Hosptal. The result showed that 58 respondents (54.7\%) experienced insomnia, with an average age of $47.66 \pm 13.36$ years. There were no significant relationships between insomnia with demographic, lifestyle, biological factors, shift $\mathrm{HD}$ and Kt/V hemodialysis. Insomnia had significant relationships with psychological factors (anxiety) ( $p=0.007 ; \mathrm{OR}=3.3$ ), and the length of time undergoing hemodialysis ( $p=0.040 ; O R=2.48)$. This study concluded that anxiety and duration hemodialysis became independent factors associated with the occurrence of insomnia. Further study need to investigate other variables that experienced by hemodialysis patients.
\end{abstract}

Keywords: anxiety, chronic kidney diseases, hemodialysis, insomnia

\section{Pendahuluan}

Gagal ginjal kronik (GGK) merupakan kerusakan ginjal atau penurunan kemampuan filtrasi glomerulus (Glomerular Filtration Rate/GFR) kurang dari $60 \mathrm{~mL} / \mathrm{min} / 1.73 \mathrm{~m} 2$ selama 3 bulan atau lebih yang irreversible dan didasari oleh banyak faktor (NKF K/DOQI, 2000; Kallenbach,
Gutch, Stoner \& Corca, 2005). GGK terjadi secara progresif dan melemahkan, sehingga massa ginjal yang masih ada tidak mampu lagi mempertahankan lingkungan internal tubuh (Suyono \& Waspadji, 2001; Black \& Hawk, 2005). Apabila kerusakan ini mengakibatkan laju GFR berkurang hingga di bawah $15 \mathrm{~mL} / \mathrm{min} / 1.73 \mathrm{~m}^{2}$ dan disertai kondisi uremia, maka pasien telah mengalami 
gagal ginjal tahap akhir atau disebut dengan end stage renal disease (ESRD) dan harus menjalani hemodialisis seumur hidupnya.

Jumlah pasien ESRD di Amerika pada akhir tahun 2007 mencapai 527.283 orang dan yang menjalani dialisis 368.544 orang (NKUDIC, 2010). Di Indonesia menurut Perhimpunan Nefrologi Indonesia (PERNEFRI), pada tahun 2007 terdapat sekitar 70.000 orang penderita GGK dan hanya 13.000 orang yang menjalani hemodialisis.

Hemodialisis merupakan proses penyaringan sampah metabolisme dengan menggunakan membran semi-permeabel yang bertujuan untuk mengoreksi gangguan keseimbangan cairan dan elektrolit, serta mengeliminasi sisa produk metabolisme protein (Kallenbach, 2005). Hemodialisis tidak dapat menyembuhkan atau memulihkan penyakit ginjal dan tidak mampu mengimbangi hilangnya aktivitas metabolik atau endokrin yang dilaksanakan oleh ginjal, sehingga pasien akan tetap mengalami berbagai komplikasi baik dari penyakitnya maupun juga terapinya (Mollaoglu, 2006; \& Parker, 2009).

Salah satu komplikasi yang sering dialami oleh pasien GGK yang menjalani hemodialisis adalah gangguan tidur. Gangguan tidur dialami oleh setidaknya 50-80\% pasien yang menjalani hemodialisis (Kosmadakis \& Medcalf, 2008; Merlino, et al., 2006; Mucsi, et al., 2004; Perl, et al., 2006; \& Sabry, et al., 2010) dengan prevalensi tertinggi berupa insomnia, yaitu berkisar antara 45-69.1\% (Al-Jahdali, et al., 2010; Novak, 2006; Pai, et al., 2007; \& Sabbatini, et al., 2002). Berbagai faktor yang diduga memiliki hubungan signifikan dengan terjadinya insomnia pada pasien hemodialisis, diantaranya adalah faktor demografi (Sabbatini, et al., 2002; \& Unruh, et al., 2006), faktor biologis (Mucsi, et al., 2004), faktor gaya hidup (Unruh, et al., 2006), faktor psikologis (Unruh, et al., 2006), dan faktor dialisis (Merlino, et al, 2005; Unruh, et al., 2006).

Pemahaman perawat terhadap insomnia yang dialami pasien dialisis merupakan bagian penting dalam pemberian asuhan keperawatan yang efektif. Oleh karena itu penting bagi perawat memahami dan mengetahui faktor yang berhubungan dengan kejadian insomnia pada pasien yang menjalani hemodialisis di RSUD Kota Tasikmalaya dan Garut sehingga dapat menentukan intervensi yang cepat dan tepat dalam upaya mencegah dan mengatasi insomnia. Penelitian tentang kejadian insomnia dan faktor penyebabnya di Indonesia belum banyak dilakukan, khususnya di RSUD Kota Tasikmalaya dan Garut belum pernah dilakukan, sedangkan berdasarkan fenomena yang ada pasien yang menjalani hemodialisis di rumah sakit tersebut banyak yang mengalami insomnia. Berdasarkan fenomena tersebut maka perlu diteliti faktor yang berhubungan dengan kejadian insomnia pada pasien yang menjalani hemodialisis di RSUD Kota Tasikmalaya dan Garut.

\section{Metode}

Penelitian potong lintang ini melibatkan 106 responden yang dipilih dengan teknik consecutive sampling. Penelitian dilakukan di Unit Hemodialisis RSUD Kota Tasikmalaya dan Garut setelah memeroleh persetujuan etik dari Komite Etik FIKUI.

Alat pengumpulan data yang digunakan adalah kuesioner dan lembar studi dokumentasi yang berhubungan dengan kejadian insomnia. Kuesioner yang dibuat diuji validitas dan reliabilitasnya pada 30 responden di luar sampel penelitian, dan hasil uji statistik menunjukkan kuesioner valid dan reliable.

Analisis bivariat dengan uji T dan uji Chi Square digunakan untuk mengetahui hubungan antara faktor demografi, gaya hidup, psikologis, biologis dan dialisis dengan kejadian insomnia. Analisis multivariat dengan uji regresi logistik ganda untuk mengetahui variabel yang dominan berhubungan dengan kejadian insomnia.

\section{Hasil}

Rerata usia responden adalah 48,85 (SD 13,22, rentangnya 15-80, dan CI 95\% 46,30-51,40). Tabel 1 menunjukkan faktor demografik, gaya 
Tabel 1. Faktor Demografi, Gaya Hidup, Faktor Psikologis, Faktor Biologis, Faktor Dialisis dan Kejadian Insomnia

\begin{tabular}{ccc}
\hline Variabel & Jumlah $(\mathbf{n}=106)$ & Prosentase \\
\hline
\end{tabular}

DEMOGRAFI

1. Jenis Kelamin

Laki-laki

Perempuan

2. Tingkat Pendidikan

Tinggi

Rendah

3. Status Pekerjaan

Bekerja

Tidak bekerja

4. Status Perkawinan

Menikah

Belum/janda/duda

GAYA HIDUP

1. Kebiasaan Merokok Ya

Tidak

2. Konsumsi Kopi

Ya

Tidak

\section{FAKTOR PSIKOLOGIS}

1. Cemas ringan

2. Cemas berat

\section{FAKTOR BIOLOGIS}

Penyakit Penyebab GGK

Hipertensi

Glomerulonefritis

Penyakit lain

Adekuasi Nutrisi

Adekuat

Tidak adekuat

\section{Anemia}

Ya

Tidak

Kadar kalsium

Normal

Rendah

\section{FAKTOR DIALYSIS}

Shift HD

Pagi

Siang

Lama waktu menjalani HD

Baru

KT/V HD

$\geq 1,8$

$<1,8$

KEJADIAN INSOMNIA 
hidup, faktor psikologis, faktor biologis, faktor dialisis, dan kejadian insomnia. Responden mayoritas laki-laki $(67 \%)$, berpendidikan tinggi $(63,2 \%)$ tetapi tidak bekerja $(65,1 \%)$, dan menikah $(95 \%)$. Responden lebih banyak yang tidak mempunyai kebiasaan merokok $(92,5 \%)$ dan minum kopi (95,3\%). Responden yang mengalami cemas berat sebanyak 53.8\%. Faktor penyebab GGK terbanyak adalah hipertensi $(69,8 \%)$, status nutrisi berimbang antara yang adekuat dan tidak, tetapi mayoritas mengalami anemia (83\%) dan berkadar kalsium rendah $(95,3 \%)$. Mayoritas responden baru menjalani hemodialisis kurang dari 1,8 tahun.

Tabel 2 menunjukkan rerata usia responden yang mengalami insomnia adalah 47,66 tahun dengan standar deviasi 13,357 tahun, sedangkan untuk responden yang tidak mengalami insomnia rerata umurnya adalah 50,29 tahun dengan standar deviasi 13,048 tahun. Hasil uji statistik didapatkan nilai $\mathrm{p}=0,309$, berarti pada alpha $5 \%$ terlihat tidak ada perbedaan yang signifikan rata-rata umur antara yang mengalami insomnia dengan yang tidak insomnia.

Tabel 3 menunjukkan tidak ada hubungan antara kejadian insomnia dengan jenis kelamin $(\mathrm{p}=0,493$; $\alpha=0,05)$, tingkat pendidikan ( $p=0,374 ; \alpha=0,05)$, pekerjaan $(\mathrm{p}=0,760 ; \alpha=0,05)$, status perkawinan $(\mathrm{p}=0,751 ; \alpha=0,05)$, kebiasaan merokok $(\mathrm{p}=0,288$; $\alpha=0,05)$ dan konsumsi kopi $(0,374 ; \alpha=0,05)$. Kejadian insomnia berhubungan dengan kecemasan pasien $(\mathrm{p}=0,038 ; \alpha=0,05)$. Dari hasil analisis diperoleh pula nilai Odd Ratio $(\mathrm{OR})=2,467$, artinya responden yang mengalami kecemasan berat

Tabel. 2 Analisis Usia Responden menurut Kejadian Insomnia

\begin{tabular}{lccccc}
\hline \multicolumn{1}{c}{ Insomnia } & Mean & SD & SE & P value & N \\
\hline Tidak & 50,29 & 13,048 & 1,883 & 0,309 & 48 \\
Ya & 47,66 & 13,357 & 1,754 & & 58 \\
\hline
\end{tabular}

Tabel 3. Kejadian Insomnia dan Faktor Demografi, Gaya Hidup dan Psikologis Pada Pasien Yang Menjalani Hemodialisis

\begin{tabular}{|c|c|c|c|c|c|c|c|c|}
\hline \multirow{3}{*}{ Variabel } & \multicolumn{4}{|c|}{ Insomnia } & \multicolumn{2}{|c|}{ Total } & \multirow[t]{3}{*}{ OR } & \multirow[t]{3}{*}{ P value } \\
\hline & \multicolumn{2}{|c|}{ Tidak } & \multicolumn{2}{|c|}{$\mathbf{Y a}$} & \multirow{3}{*}{ n (106) } & \multirow[b]{2}{*}{$\%$} & & \\
\hline & n (48) & $\%$ & n (58) & $\%$ & & & & \\
\hline Jenis Kelamin & & & & & & & & 0,493 \\
\hline Laki-laki & 30 & 42,3 & 41 & 57,7 & 71 & 100 & 0,691 & \\
\hline Perempuan & 18 & 51,4 & 17 & 48,6 & 35 & 100 & $(0,31-1,56)$ & \\
\hline \multicolumn{9}{|l|}{ Pendidikan } \\
\hline Tinggi & 29 & 43,3 & 38 & 56,7 & 67 & 100 & 0,803 & \\
\hline Rendah & 19 & 48,7 & 20 & 51,3 & 39 & 100 & $(0,36-1,77)$ & 0,734 \\
\hline \multicolumn{9}{|l|}{ Pekerjaan } \\
\hline Bekerja & 18 & 48,6 & 19 & 51,4 & 37 & 100 & 1,232 & \\
\hline Tidak & 30 & 43,5 & 39 & 56,5 & 69 & 100 & $(0,55-2,75)$ & 0,760 \\
\hline \multicolumn{9}{|l|}{ Perkawinan } \\
\hline Menikah & 44 & 46,3 & 51 & 53,7 & 95 & 100 & 1,510 & \\
\hline Tidak & 4 & 36,4 & 7 & 63,6 & 11 & 100 & $(0,41-5,50)$ & 0,751 \\
\hline \multicolumn{9}{|l|}{ Merokok } \\
\hline Tidak & 46 & 46,9 & 52 & 53,1 & 98 & 100 & 2,654 & \\
\hline Ya & 2 & 25 & 6 & 75 & 8 & 100 & $(0,51-13,8)$ & 0,288 \\
\hline \multicolumn{9}{|l|}{ Kopi } \\
\hline Tidak & 47 & 46,5 & 54 & 53,5 & 101 & 100 & 3,481 & \\
\hline $\mathrm{Ya}$ & 1 & 20 & 4 & 80 & 5 & 100 & $(0,38-32,2)$ & 0,374 \\
\hline \multicolumn{9}{|l|}{ Cemas } \\
\hline Ringan & 28 & 57,1 & 21 & 42,9 & 49 & 100 & 2,467 & \\
\hline Berat & 20 & 35,1 & 37 & 64,9 & 57 & 100 & $1,13-5,41$ & 0,038 \\
\hline
\end{tabular}


mempunyai peluang 2,467 kali untuk mengalami insomnia dibandingkan responden yang mengalami kecemasan ringan.

Tabel 4 menunjukkan tidak ada hubungan antara kejadian insomnia dengan penyakit penyebab GGK $(\mathrm{p}=0,565 ; \alpha=0,05)$, kondisi anemia $(\mathrm{p}=$ $0,735 ; \alpha=0,05)$, status nutrisi $(\mathrm{p}=1,00 ; \alpha=0,05)$, kadar kalsium plasma $(\mathrm{p}=0,808 ; \alpha=0,05)$, shift hemodialisis $(\mathrm{p}=0,956 ; \alpha=0,05)$, lama menjalani hemodialisis $(p=0,249 ; \alpha=0,05)$ dan adekuasi hemodialisis (Kt/V) $(\mathrm{p}=0,753$ dan $\alpha=$ $0,05)$.

Hasil analisis multivariat menunjukkan bahwa variabel yang berhubungan dengan kejadian in- somnia adalah variabel kecemasan dan lama waktu menjalani hemodialisis. Variabel kecemasan merupakan faktor yang dominan berhubungan dengan insomnia, dengan nilai Odds ratio (OR) $=3,301$, artinya individu yang mengalami kecemasan berat berisiko 3,3 kali untuk mengalami insomnia dibandingkan dengan individu yang mengalami kecemasan ringan setelah dikontrol variabel lama waktu menjalani HD. Selain itu, hasil analisis didapatkan Odds Ratio (OR) = 2,477 untuk variabel lama waktu menjalani HD, artinya individu yang menjalani HD dalam waktu lama berisiko 2,5 kali untuk mengalami insomnia dibandingkan dengan individu yang baru menjalani HD setelah dikontrol variabel kecemasan.

Tabel 4. Kejadian Insomnia dan Faktor Biologis dan Faktor Dialysis Pada Pasien yang Menjalani Hemodialisis

\begin{tabular}{|c|c|c|c|c|c|c|c|c|}
\hline \multirow{3}{*}{ Variabel } & \multicolumn{4}{|c|}{ Insomnia } & \multirow{2}{*}{\multicolumn{2}{|c|}{ Total }} & \multirow{3}{*}{ OR } & \multirow{3}{*}{$\mathbf{p}$} \\
\hline & \multicolumn{2}{|c|}{ Tidak } & \multicolumn{2}{|c|}{$\mathbf{Y a}$} & & & & \\
\hline & n (48) & $\%$ & n (58) & $\%$ & n (106) & $\%$ & & \\
\hline \multicolumn{9}{|l|}{ Penyebab GGK } \\
\hline $\mathrm{DM}$ & 8 & 50 & 8 & 50 & 16 & 100 & & \multirow{4}{*}{0,565} \\
\hline Hipertensi & 34 & 45,9 & 40 & 54,1 & 74 & 100 & 1,176 & \\
\hline GN & 3 & 60 & 2 & 40 & 5 & 100 & 0,667 & \\
\hline Peny. Lain & 3 & 27,3 & 8 & 72,7 & 11 & 100 & 2,667 & \\
\hline \multicolumn{9}{|l|}{ Anemia } \\
\hline Tidak & 7 & 38,9 & 11 & 61,1 & 18 & 100 & 0,729 & \multirow{2}{*}{0,735} \\
\hline Ya & 41 & 46,6 & 47 & 53,4 & 88 & 100 & $(0,26-2,06)$ & \\
\hline \multicolumn{9}{|l|}{ Nutrisi } \\
\hline Adekuat & 24 & 45,3 & 29 & 54,7 & 53 & 100 & 1,000 & \multirow{2}{*}{1,000} \\
\hline Tidak & 24 & 45,3 & 29 & 54,7 & 53 & 100 & $(0,47-2,15)$ & \\
\hline \multicolumn{9}{|l|}{ Kalsium } \\
\hline Normal & 2 & 40 & 3 & 60 & 5 & 100 & 0,797 & \multirow{2}{*}{0,808} \\
\hline Rendah & 46 & 45,5 & 55 & 54,5 & 101 & 100 & $(0,13-4,98)$ & \\
\hline \multicolumn{9}{|l|}{ Shift HD } \\
\hline Pagi & 26 & 46,4 & 30 & 53,6 & 56 & 100 & 1,103 & \multirow[b]{2}{*}{0,956} \\
\hline Siang & 22 & 44 & 28 & 56 & 50 & 100 & $(0,51-2,37)$ & \\
\hline \multicolumn{9}{|l|}{ Lama HD } \\
\hline Baru & 27 & 51,9 & 25 & 48,1 & 52 & 100 & 1,697 & \multirow{2}{*}{0,249} \\
\hline Lama & 21 & 38,9 & 33 & 61,1 & 54 & 100 & $0,79-3,67$ & \\
\hline \multicolumn{9}{|l|}{$\mathrm{Kt} / \mathrm{V}$} \\
\hline$\geq 1,8$ & 5 & 50 & 5 & 50 & 10 & 100 & 1,233 & \multirow{2}{*}{0,753} \\
\hline$<1,8$ & 43 & 44,8 & 53 & 55,2 & 96 & 100 & $(0,34-4,54)$ & \\
\hline
\end{tabular}

Tabel 5. Analisis Multivariat Variabel Kecemasan dan Lama Waktu Menjalani Hemodialisis

\begin{tabular}{lccccc}
\hline Variabel & B & Wald & p $\boldsymbol{V}$ & OR & 95\% CI \\
\hline Kecemasan & 1,19 & 7,283 & 0,007 & 3,30 & $1,39-7,86$ \\
Lama HD & 0,91 & 4,210 & 0,040 & 2,48 & $1,04-5,89$ \\
\hline
\end{tabular}




\section{Pembahasan}

Beberapa penelitian melaporkan tingginya kejadian insomnia pada pasien GGK yang menjalani hemodialisis. Sejalan dengan penelitian tersebut, hasil penelitian ini juga menemukan bahwa kejadian insomnia pada pasien yang menjalani hemodialisis cukup tinggi, yaitu sekitar 54,7\% dari 106 responden. Jumlah ini lebih tinggi jika dibandingkan dengan hasil penelitian yang dilakukan oleh Sabbatini, et al. (2002), namun sedikit lebih rendah jika dibandingkan dengan hasil penelitian Al-Jahdali, et al. (2010). Tingginya angka kejadian insomnia pada penelitian ini berhubungan dengan tingginya jumlah responden yang mengalami kecemasan berat $(53,8 \%)$, dimana kondisi tersebut dilaporkan memiliki hubungan yang signifikan dengan kejadian insomnia (Paparrigopoulos, et al. 2009)

Hasil analisis univariat menunjukkan bahwa insomnia lebih banyak terjadi pada responden yang berjenis kelamin laki-laki dan berumur lebih muda. Rata-rata umur reponden yang mengalami insomnia dalam penelitian ini adalah 47,66 tahun, sedangkan yang tidak mengalami insomnia 50,29 tahun. Penemuan ini cukup mengejutkan, karena beberapa penelitian sebelumnya justru menyebutkan sebaliknya, dimana insomnia lebih sering terjadi pada orang lanjut usia dan wanita (Han, et al. 2002; Ohayon, et al. 2002). Menurut peneliti, hal tersebut disebabkan karena responden laki-laki dalam penelitian ini termasuk dalam usia produktif, dimana seharusnya dalam usianya tersebut mereka masih produktif dan bisa berperan sebagai kepala keluarga, sementara karena penyakitnya, mereka justru memiliki banyak ketidakmampuan, bahkan sebagian besar terpaksa harus kehilangan pekerjaannya (Kimmel, 2002).

Perubahan peran dan tanggung jawab yang dialami para kepala keluarga menyebabkan mereka merasa bersalah dan merasa terancam harga dirinya, sehingga pasien akan menjadi cemas dan depresi dengan keadaanya (Kimmel, 2002). Hal tersebut dibuktikan oleh banyaknya jumlah responden yang mengalami cemas berat $(53,8 \%)$. Sejalan dengan pendapat diatas, Anees, et al. (2008) melaporkan bahwa faktor risiko utama terjadinya depresi pada pasien HD adalah lakilaki, status marital, jumlah anak dan faktor sosioekonomik.

Selain tidak berhubungan dengan usia dan jenis kelamin, insomnia juga tidak berhubungan dengan faktor demografi lainnya, yaitu pendidikan ( $\mathrm{p}$ value 0,734 ), pekerjaan ( $\mathrm{p}$ value 0,760 ) dan status perkawinan ( $\mathrm{p}$ value 0,751 ). Walaupun dalam analisis univariat kejadian insomnia lebih sering terjadi pada usia muda dan jenis kelamin laki-laki, namun hasil analisis lebih lanjut menunjukkan tidak ada hubungan antara kejadian insomnia dengan usia dan jenis kelamin $(\mathrm{p}=$ $0,309$ dan $\mathrm{p}=0,493)$. Berbeda dengan penelitian Merlino, et al. (2006) yang melaporkan bahwa variabel umur merupakan prediktor independen dan signifikan terhadap gangguan tidur pada pasien ESRD yang menjalani hemodialisis, dengan $\mathrm{p}$ value 0,001 . Perbedaan tersebut terjadi karena rata-rata umur responden dalam penelitian Merlino, et al. (2006) lebih tua daripada penelitian ini, yaitu 64,95 tahun.

Penelitian ini juga menemukan tidak ada hubungan antara insomnia dengan penyakit penyebab GGK ( $\mathrm{p}$ value 0,565$)$, anemia ( $\mathrm{p}$ value 0,735 ), adekuasi nutrisi ( $\mathrm{p}$ value 1,000 ) dan kadar kalsium ( $\mathrm{p}$ value 0,808). Hasil penelitian ini sejalan dengan hasil penelitian Al Jahdali, et al (2010) yang juga menemukan tidak ada hubungan antara penyakit penyebab GGK, anemia, adekuasi nutrisi dan kadar kalsium plasma dengan kejadian insomnia.

Penelitian ini menemukan bahwa faktor psikologis (tingkat kecemasan) memiliki hubungan dengan kejadian insomnia dan juga merupakan faktor yang dominan berhubungan dengan kejadian insomnia ( $\mathrm{p}$ value 0,007 ; OR 3,301). Penelitian ini sejalan dengan penelitian yang dilakukan oleh Sabry, et al (2010), yang melaporkan bahwa insomnia berhubungan dengan kecemasan.

Individu dengan hemodialisis jangka panjang sering merasa khawatir akan kondisi sakitnya yang tidak dapat diramalkan dan menimbulkan gangguan dalam kehidupannya. Mereka biasanya menghadapi masalah finansial, kesulitan dalam mempertahankan pekerjaan, dorongan seksual 
yang menghilang serta impotensi, depresi akibat sakit yang kronis dan ketakutan terhadap kematian (Smeltzer \& Bare, 2002).

Stress atau kecemasan yang dialami pasien dapat merangsang sistem saraf simpatis untuk mengeluarkan katekolamin, glucagon dan hormon kortisol-steroid yang mempengaruhi SSP dalam meningkatkan rasa gelisah, frustasi, nafas cepat, hipertensi dan ketegangan otot. Demikian juga dapat menstimulasi fungsi Reticular Activating System (RAS) yang mengatur seluruh fase siklus tidur, meningkatkan sleep latency dan menurunkan efisiensi tidur yang meliputi peningkatan frekuensi bangun di malam hari (Robbins, et al., 2004).

Hubungan kecemasan dengan insomnia memiliki hubungan yang timbal balik, dimana individu yang mengalami insomnia umumnya akan mengalami peningkatan kecemasan, demikian juga sebaliknya, individu yang mengalami kecemasan bisa mengalami kesulitan tidur/insomnia.

Kecemasan merupakan bagian integral dari insomnia, dimana kekhawatiran akan tidur merupakan salah satu faktor pencetus dari kronik insomnia. Banyak individu dengan insomnia mengalami kecemasan pada saat menjelang tidur karena takut tidak bisa tidur dan konsekuensi yang akan mereka alami pada siang harinya. Peningkatan kecemasan ini bisa meningkatkan "arousal" pada saat "arousal state" seharusnya menurun, sehingga akhirnya menurunkan kesempatan untuk tidur, dan terjadilah siklus insomnia - kecemasan (Nutt \& Wilson, 2008). Pendapat diatas didukung oleh penelitian Breslau, et al. (1996) yang menemukan adanya peningkatan kecemasan 2 kali lipat pada individu yang mengalami insomnia dibandingkan individu yang tidurnya baik.

Berdasarkan hal tersebut, penting bagi perawat unit HD dan tim medis untuk melakukan skrining kecemasan dan insomnia, karena kedua hal tersebut bisa saling mempengaruhi dan secara umum dapat menurunkan kualitas hidup pasien HD. Perawat dapat mengidentifikasi kecemasan dan insomnia dengan melakukan pengkajian yang komprehensif, tidak hanya faktor biologis tapi juga meliputi psikologis, sosial dan spiritual pasien. Setelah diagnosis kecemasan ditegakkan, maka seorang perawat spesialis dapat menerapkan berbagai manajemen untuk mengatasi kecemasan, misalnya dengan terapi relaksasi (progressive muscle relaxations, terapi musik, yoga, dan sebagainya) serta pengembangan koping konstruktif untuk mencegah gangguan psikologis yang lebih berat sehingga pasien terhindar dari keluhan insomnia.

Penelitian ini juga menemukan hubungan antara insomnia dengan lama waktu menjalani hemodialisis ( $\mathrm{p}=0,040 ; \mathrm{OR}=2,477 ; 95 \%$ CI 1,041 $-5,893)$. Penelitian ini sejalan dengan penelitian Sabbatini et al. (2002) yang melaporkan bahwa secara signifikan terdapat risiko tinggi terjadinya insomnia pada pasien yang sudah menjalani hemodialisis dalam waktu lama $(\mathrm{p}<0,005)$. Sabbatini, et al. (2002) mengungkapkan tingginya kejadian insomnia pada pasien yang menjalani hemodialisis dalam waktu lama berhubungan dengan makin progresifnya gejala dan penyakit yang mendasari terapi dialisis, atau oleh karena munculnya komplikasi, seperti masalah kardiovaskuler dan neurologis yang sering muncul pada pasien dialysis jangka panjang. Demikian juga Coccossis, et al. (2008) menyatakan bahwa pasien yang menjalani hemodialisis dalam jangka panjang sering mengalami peningkatan defisit fisik dan sosial, serta mengalami penurunan kualitas hidup sejalan dengan penurunan kesehatan mental.

Diketahuinya hubungan antara lama HD dengan kejadian insomnia, maka hal tersebut seharusnya menjadi perhatian bagi perawat dan tim medis untuk memberikan kualitas HD yang optimal sesuai standar yang telah ditetapkan. Adekuasi HD merupakan faktor utama yang harus diperhatikan, karena dengan HD yang adekuat maka pasien akan terhindar dari kondisi toksisitas uremik, sehingga walaupun pasien sudah melakukan HD dalam waktu lama, namun bisa tetap terhindar dari morbiditas dan mortalitas yang bisa terjadi akibat pelaksanaan HD yang tidak adekuat.

Penelitian ini tidak menemukan hubungan adekuasi hemodialisis (Kt/V) dengan insomnia, namun hasil tersebut belum tentu tidak ber- 
hubungan secara klinis. Kenyataannya, jika bersihan ureum setelah HD tidak optimal maka pasien akan mengalami berbagai gangguan fisik, seperti gatal-gatal, mual, pusing, nyeri dan keluhan lainnya yang bisa menyebabkan aktivasi RAS sehingga pasien menjadi tidak bisa tidur. Penelitian ini tidak mengidentifikasi keluhan fisik yang biasa dialami pasien uremik, sehingga di masa yang akan datang perlu diidentifikasi dan dicari hubungannya dengan kejadian insomnia.

Selain faktor psikologis dan lama waktu menjalani hemodialisis yang memiliki hubungan dengan kejadian insomnia pada pasien hemodialisis, penelitian ini tidak menemukan hubungan antara kejadian insomnia dengan faktor gaya hidup, faktor biologis, shift HD dan Kt/V hemodialisis.

\section{Kesimpulan}

Insomnia dialami oleh 54,7\% dari 106 responden yang menjalani hemodialisis yang tidak berhubungan dengan faktor demografi, gaya hidup, faktor biologis, shift HD dan Kt/V hemodialisis. Pasien yang menjalani HD dalam waktu lama memiliki risiko 2,477 kali untuk mengalami insomnia dibandingkan pasien yang baru menjalani HD, sedangkan kecemasan merupakan faktor yang dominan berhubungan dengan kejadian insomnia. Pasien yang mengalami kecemasan berat memiliki risiko 3,3 kali untuk mengalami insomnia dibandingkan pasien yang mengalami kecemasan ringan.

Kemampuan perawat, perlu ditingkatkan terutama perawat spesialis medikal bedah dalam mengidentifikasi berbagai masalah yang dialami pasien, tidak hanya faktor fisik tapi juga faktor psikologis dan masalah lainnya secara komprehensif. Perawat diharapkan dapat melakukan skrining kecemasan dan insomnia pada pasien yang menjalani HD dengan menanyakan secara langsung gejala insomnia kepada pasien atau dengan mempelajari sleep diary's pasien.

Perawat perlu mengembangkan intervensi untuk mencegah ataupun menangani insomnia yang sering dialami pasien GGK yang menjalani hemodialisis, misalnya dengan melakukan teknik relaksasi, terapi perilaku kognitif, dan pendidikan kesehatan tentang sleep hygiene. Perawat dan tim medis di unit HD juga dapat memberikan hemodialisis yang adekuat, sehingga walaupun pasien sudah menjalani HD dalam waktu lama, pasien dapat terhindar dari komplikasi penyakit dan komplikasi terapi hemodialisis yang bisa menyebabkan insomnia (US, RS).

\section{Referensi}

Anees, M., Barki, H., Masood, M., Ibrahim, M., \& Mumtaz, A. (2008). Depression in hemodialysis patients. Pak J Med Sci, 24(4), 560-565.

Al-Jahdali, H., Khogeer, H.A., Al-Qadhi, W.A., Baharoon, S., Tamim, H., Al-Hejaili, F.F., M Al-Ghamdi, S.M., \& Al-Sayyari, A.A. (2010) Insomnia in Chronic Renal Patients on Dialysis in Saudi Arabia. Journal of Circadian Rhythms, 8 (7). doi:10.1186/17403391-8-7.

Black, J.M \& Hawks, J.H. (2005) Medical surgical nursing clinical management for positive outcomes (7th Ed.). St Louis: Elsevier Saunders.

Breslau, N., Roth, T., Rosenthal, L., \& Andreski, P. (1996). Sleep disturbance and psychiatric disorders: a longitudinal epidemiological study of young adults. Biol Psychiatry; 39: 411-18.

Coccossis, M.G., Theofilou, P., Synodinou, C., Tomaras, V., Soldatos, C. (2008). Quality of life, mental health and healthbeliefs in hemodialysis patients and peritoneal dialysis patients: Investigating differences in early and later years of currens treatments. $B M C$ Nephrols; 9:14.

Han, S. Y., Yoon, J. W., Jo, S. K., Shin, J. H., Shin, C., Lee, J. B., et al. (2002). Insomnia in diabetic hemodialysis patients. Prevalence and risk factors by a multicenter study. Nephron, 92(1), 127-132.

Kallenbach, J.Z., Gutch, C.F., Stoner, M.H., \& Corea, A.L. ( 2005) Review of hemodialysis for nurse and dialysis peersonel. St. Louis: Mosby 
Kimmel, P.L. (2002). Depresion in patients with chronic renal disease: What we know and what we need to know. J Psychosom Res, 53: 951-956

Kosmadakis, G.C., \& Medcalf, J.F. (2008) Sleep disorders in dialysis patients. Int $J$ Artif Organs; 31(11), 919-27.

Merlino, P.G., Dolso, P., Adorati, M., Cancelli, I., Valente, M., Gigli, G.L. (2006) Sleep disorders in patients with end stage renal disease undergoing dialysis therapy. Nephrol Dial Transplant; 21(1), 184-190.

Mucsi, I., Molnar, M.Z., Rethelyi, J., Vamos, E., Csepanyi, G., Tompa, et al. (2004). Sleep disorders and illness intrusiveness in patients on chronic dialysis. Nephrol Dial Transplant; 19(7), 1815-1822.

Mucsi, I., Molnar, M.Z., Ambrus, C., Szeifert L, Kovacs, A.Z., Zoller, R., et al. (2005). Restless leg syndrome, insomnia and quality of life in patients on maintenance dyalisis. Nephrol Dial Transp; 20(3):571-577.

Mollaoglu, M. (2009). Perceived social support, anxiety, and self-care among patients receiving hemodialysis. Dyalisis \& Transplantation. 35(3), 144-155. doi: 10.1002/dat.20002

NKUDIC. (2010). Kidney and urologic diseases statistics for the united states.

National Kidney Foundation (2000). K/DOQI clinical Practice Guideline for chronic Kidney disease: evaluations, classification, and stratification.

Novak, M., Shapiro, C.M., Mendelssohn, D., \& Mucsi, I. (2006) Diagnosis and Management of Insomnia in Dialysis Patients. Seminar in Dialysis,19(1): 25-31.

Nutt, D., \& Wilson, S. (2008). Anxiety and Insomnia Bidirectional Association. European Psychiatric Review. Diperoleh dari: http://www.touchophthalmology.com/sites/www.touchoncology. com/files/migrated/articles_pdfs/wilson.pdf.

Ohayon, M.M. (2002). Epidemiology of insomnia: What we know and what we still need to learn. Sleep Med Rev, 6(2); 97-111.
Pai, M.F., Hsu, S.P., Yang, S.Y., Ho, T.I., Lai, C.F., \& Peng, Y.S. (2007). Sleep disturbance in chronic haemodialysis patients: The impact of depression and anemia. Renal Failure; 29(6); 673-677.

Paparrigopoulus, T., Tzavara, C., Theleritis C., Psarros, C., Soldatos, C., \& Tountas, Y. (2010). Insomnia and it's correlates in a representative sample of The Greek population. BMC Public Health, 3(10): 531. doi:10.1186/1471-2458-10-531.

Parker, D. (2009). Facing dialysis, depression and anxiety. Health Voices, 5. ISSN: 18355862.

Pernefri. (2003). Konsensus Dialisis Perhimpunan Nefrologi Indonesia. Jakarta

Perl, J., Unruh, M.L., \& Chan, C.T. (2006). Sleep disorders in ESRD: Markers of inadequate dialysis? Kidney Int. 70(10):1687-93.

Sabbatini, M., Minale, B., Crispo, A., Ragosta, A., Esposito R, Cesaro A, Cianciaruso B, Andreucci VE. (2002) Insomnia in Maintenance Hemodialysis Patients. Nephrology Dialysis Transplantation 17: 852-856.

Sabry, A.A., Zenah, H.A., Wafa, E., Mahmoud, K., El-Dahshan, K., Hassan A., et al. (2010). Sleep disorders in hemodialysis patients. Saudi Journal of Kidney Diseases and Transplantion, 21(2):300-305.

Smeltzer, S.C., Bare, B.G., Hinkle, J.L., \& Cheever, K.H. (2008) Brunner \& Suddarth's Textbook of medical-surgical nursing (11th Ed.). Philadelphia: Lippincott William \& Wilkins.

Suyono, S., \& Wapadji. (2001). Buku ajar penyakit dalam Jilid II Edisi ketiga. Jakarta: FKUI.

Unruh, M.L., Buysse, D.J., Dew, M.A., Evans, I.V., Wu, A.W., Fink, N.E., et al. (2006). Sleep quality and its correlates in the first year of dialysis. Clin J Am Soc Nephrol, 1 (4), 802-810. 